\title{
KARAKTERISTIK FISIK, KIMIA DAN ORGANOLEPTIK SELAI PADA BERBAGAI RASIO BUAH NAGA MERAH (Hylocereus polyrhizus Britt and Rose) - GULA PASIR
}

\section{PHYSICAL, CHEMICAL AND ORGANOLEPTIC CHARACTERISTICS OF THE OCEAN IN VARIOUS RED DRAGON RATIO (Hylocereus polyrhizus Britt and Rose) - SAND SUGAR}

\author{
Huriah $^{1}$, Nur Alam ${ }^{2 *}$, Abd. Hamid Noor ${ }^{2}$ \\ ${ }^{1}$ Alumni Program Studi Agroteknologi, Fakultas Pertanian, Universitas Tadulako \\ ${ }^{2}$ Program Studi Agroteknologi, Fakultas Pertanian, Universitas Tadulako \\ Jalan. Soekarno Hatta Km 9 Palu 94118, Indonesia
}

\begin{abstract}
ABSTRAK
Tingginya kadar air pada buah naga mengakibatkan buah tersebut mudah rusak, oleh karena itu perlu diolah untuk mengurangi jumlah kerugian, antara lain dibuat menjadi selai. Selain itu pengolahan buah naga menjadi berbagai macam produk olahan juga bertujuan untuk mengatasi masalah kelebihan produksi saat musim panen tiba. Penelitian bertujuan untuk mendapatkan rasio buah naga-gula pasir yang memberikan pengaruh terbaik terhadap karakteristik fisik, kimia dan organoleptik selai. Penelitian menggunakan Rancangan Acak Lengkap (RAL) untuk analisis parameter fisik selai (kelunakan) dan kimia selai (kadar air, total padatan terlarut, kadar antosianin dan vitamin C). Rancangan Acak Kelompok (RAK) untuk analisis parameter uji organoleptic (warna, tekstur, rasa dan kesukaan). Sebagai perlakuan adalah rasio daging buah naga-gula pasir yang terdiri dari lima taraf perlakuan yaitu $\mathrm{P} 1=$ buah naga $450 \mathrm{~g}$ : gula pasir $550 \mathrm{~g}, \mathrm{P} 2=$ buah naga $500 \mathrm{~g}$ : gula pasir $500 \mathrm{~g}, \mathrm{P} 3=$ buah naga $550 \mathrm{~g}$ : gula pasir $450 \mathrm{~g}, \mathrm{P} 4$ = buah naga $600 \mathrm{~g}$ : gula pasir $400 \mathrm{~g}, \mathrm{P} 5=$ buah naga $650 \mathrm{~g}$ : gula pasir $350 \mathrm{~g}$. Setiap perlakuan diulang sebanyak 3 kali sehingga terdapat 15 unit percobaan. Data yang telah diperoleh dianalisis menggunakan uji F 0,01 dan 0,05. Jika perlakuan berpengaruh nyata atau sangat nyata maka dilanjutkan dengan uji BNJ pada tararf 0,01 dan 0,05. Hasil penelitian menunjukan bahwa perlakuan P4 (rasio buah naga-gula pasir $600: 400 \mathrm{~b} / \mathrm{b}$ ) memberikan pengaruh terbaik terhadap karakteristik fisik, kimia dan organoleptik selai buah naga. Perlakuan ini dapat mengurangi pemakaian gula pasir sebesar 15 persen dari standar penggunaan gula dalam pembuatan selai.
\end{abstract}

Kata kunci : karakteristik selai, buah naga, gula pasir

\section{ABSTRACT}

The high water content in dragon fruit causes the fruit to be easily damaged, therefore it needs to be processed to reduce the amount of loss, including making it into jam. In addition, processing dragon fruit into various processed products also aims to overcome the problem of excess production when the harvest season arrives. The aim of this research was to obtain the ratio of dragon-sugar fruit which gave the best influence on the physical, chemical and organoleptic characteristics of jam. The study used a completely randomized design (CRD) for the analysis of physical parameters of jam (softness) and chemical jam (water content, total dissolved solids, anthocyanin and vitamin C levels). Randomized Group Design (RBD) for analysis of organoleptic test parameters (color, texture, taste and preference). As a treatment, it is the ratio of dragon-sugar, which consists of five levels of treatment, namely $P 1=$ dragon fruit $450 \mathrm{~g}:$ granulated sugar $550 \mathrm{~g}, P 2=$ dragon fruit $500 \mathrm{~g}:$ granulated sugar 500 $\mathrm{g}, \mathrm{P3}=$ dragon fruit $550 \mathrm{~g}:$ sugar $450 \mathrm{~g}, \mathrm{P} 4=$ dragon fruit $600 \mathrm{~g}:$ granulated sugar $400 \mathrm{~g}, \mathrm{P} 5=$ dragon fruit $650 \mathrm{~g}$ : granulated sugar $350 \mathrm{~g}$. Each treatment was repeated 3 times so that there were 15 experimental units. The data obtained were analyzed using $F$ test 0.01 and 0.05 . If the treatment has a significant or very real effect, then proceed with the BNJ test at tararf 0.01 and 0.05. The results showed that treatment $P 4$ (600: $400 \mathrm{~b} / \mathrm{b}$ dragon-sugar ratio) gave the best influence on the physical, chemical and organoleptic characteristics of dragon fruit jam. This treatment can reduce the use of sugar by 15 percent from the standard use of sugar in making jam.

Keywords: characteristics of jam, dragon fruit, granulated sugar 


\section{Pendahuluan}

Tanaman buah naga merah (Hylocereus polyrhizus) dibudidayakan secara intensif di beberapa negara sepertilsrael, Colombia, Nikaragua, Vietnam, Thailand, Cina, dan Australia (Lichtenzveig, et al., 2000). Buah naga dapat dikonsumsi dalam bentuk segar maupun olahan. Rasanya cukup manis karena mengadung total gula dalam buah yang cukup tinggi. Menurut Jerônimo, et al., (2015) buah naga mengandung air $86,03 \%$, mineral $0,75 \%$, lipid $0,16 \%$, protein $2,27 \%$, total karbohidrat $10,79 \%$, pH 5,05, serat kasar $1,15 \%$, total asam 1,82\%, total gula $5,92 \%$, total padatan $13,97 \%$, padatan terlarut 11,40 (Brix pada suhu $20^{\circ} \mathrm{C}$ ). Selain itu buah naga juga mengandung vitamin $\mathrm{C} 8-9$ $\mathrm{mg} / 100 \mathrm{~g}$ (Jaafar, et al., 2009), 9, $90 \mathrm{mg} / 100 \mathrm{~g}$ (Islam, et al., 2012), 9,4 mg/100 g (Kristanto, 2013).

Selain dibudidayakan sebagai tanaman buah, buah naga juga dibudidayakan sebagai tanaman obat karena memiliki khasiat untuk kesehatan manusia. Khasiat tersebut antara lain sebagai penyeimbang gula darah, pencegah kanker usus, pelindung kesehatan mulut, pengurang kolestrol, pencegah pendarahan, dan obat keluhan keputihan. Mahattanatawee et al, (2006) buah naga merah memiliki zat antioksidan yaitu $1075,8 \pm 71,7 \mathrm{TSP}$ ( $\mu \mathrm{g} \mathrm{GA} / \mathrm{g}$ purce), 55,8 $\pm 2,0$ TAA $(\mathrm{mg} / 100 \mathrm{~g}$ purce), 7,6 $\pm 0,1$ ORAC $(\mu \mathrm{M}$ $\mathrm{TE} / \mathrm{g}$ purce) dan $134,1 \pm 30,1 \mathrm{DPPH}(\mu \mathrm{g} \mathrm{GA} / \mathrm{g}$ purce), lebih tinggi jika dibandingkan dengan buah naga putih.Antosianin yang terkandung dalam buah naga merah 28,7 sampai 55,6 mg/100g buah segar (Vargas, et al., 2013).

Tingginya kadar air pada buah naga mengakibatkan buah tersebut mudah rusak. Oleh karena itu buah naga merah perlu diolah untuk mengurangi jumlah kerugian, antara lain dibuat menjadi selai.Selain itu pengolahan buah naga menjadi berbagai macam produk olahan juga bertujuan untuk mengatasi masalah kelebihan produksi saat musim panen tiba.

Selai merupakan makanan berbentuk pasta yang diperoleh dari pemasakan bubur buah, guladan dapat ditambahkan asam serta bahan pengental. Proporsinya adalah $45 \%$ bagian berat buah dan $55 \%$ bagian berat gula. Campuran yang dihasilkan kemudian dikentalkan sehingga hasil akhirnya mengandung total padatan terlarut

\footnotetext{
${ }^{*}$ Penulis Korespondensi.

E-mail: alam_thp60@yahoo.co.id

Telp: +62-82191784999
}

minimum 65\%. Faktor yang mempengaruhi pembentukan selai yaitu kadar gula, pektin dan asam. Gula dan pektin harus berada pada keseimbangan yang sama agar menghasilkan karakteristik selai yang baik. Menurut Rizky dan Addina(2012), kondisi optimum untuk pembentukan gel pada selai adalah pektin $(0,75-$ $1,5 \%)$, gula $(65-70 \%)$ dan $\mathrm{pH}(3,2-3,4)$. Dalam pembuatan selai buah harus menggunakan buah yang mengandung pektin dan asam yang cukup untuk menghasilkan selai yang baik.

Akhir-akhir ini sebagian besar masyarakat menghindari mengkomsumsi makanan yang mengandung gula berlebihan untuk mencegah penyakit diabetes. Selai termasuk makanan olahan yang diolah dengan kadar gula tinggi sehingga mengurangi animo masyarakat untuk mengkomsumsinya. Salah satu upaya yang perlu dilakukan untuk mengatasi masalah ini adalah mensubsitusi gula pasir dengan buah naga. Upaya ini selain mengurangi penggunaan gula pasir dalam pembuatan selai juga akan memberikan dampak positif bagi kesehatan. Merujuk pada uraian tersebut di atas, maka telah dilakukan penelitian dengan tujuan mendapatkan rasio buah naga-gula pasir yang memberikan pengaruh terbaik terhadap karakteristik fisik, kimia dan organoleptik selai.

\section{Metode Penelitian}

Penelitian dilaksanakan di Laboratorium Agroindustri, Fakultas Pertanian, Universitas Tadulako Palu, Sulawesi Tengah. Pelaksanaanya dimulai pada bulan Oktober 2018 - Maret 2019.

Bahan utama yang digunakan pada penelitian ini adalah buah naga merah yang diperoleh dari Desa Maku, Kecamatan Dolo Kabupaten Sigi. Sebagai bahan pembantu adalah gula pasir, asam sitrat, agar-agar, aquades, amilum $1 \%$, iodium $0,01 \mathrm{~N}$ dan ethanol : HC1 $1 \mathrm{~N}(85: 15 \mathrm{~V} / \mathrm{V})$.

Peralatan yang digunakan meliputi talenan, pisau, baskom, timbangan analitik, batang pengaduk, blender merek Philips HR 2116, kompor, panci, sendok, botol selai, gelas ukur, labu takar sentrifuge, pipet volume, erlenmeyer, kertas saring, corong gelas, spektrofotometer, refraktometer dan penetrometer

Penelitian menggunakan Rancangan Acak Lengkap (RAL) untuk analisis parameter fisik selai (kelunakan) dan kimia selai (kadar air, total padatan terlarut, kadar antosianin dan vitamin C). Rancangan Acak Kelompok (RAK) untuk analisis parameter uji organoleptic (warna, tekstur, rasa dan kesukaan). Sebagai perlakuan 
adalah rasio daging buah naga-gula pasir yang terdiri dari lima taraf perlakuan seperti yang tersaji pada (Tabel 1). Setiap perlakuan diulang sebanyak 3 kali sehingga terdapat 15 unit percobaan. Data yang diperoleh dianalisis menggunakan uji F 0,01 dan 0,05. Jika perlakuan berpengaruh nyata atau sangat nyata maka dilanjutkan dengan uji BNJ pada tararf 0,01 dan 0,05 .

Tabel 1. Formula Perlakuan Penelitian

\begin{tabular}{|c|c|c|c|c|c|}
\hline $\mathrm{N}_{0}$ & $\begin{array}{c}\text { Kode } \\
\text { Perlakuan }\end{array}$ & $\begin{array}{l}\text { Daging } \\
\text { buah nagar } \\
\text { (g) }\end{array}$ & $\begin{array}{l}\text { Gula pasi } \\
\text { (g) }\end{array}$ & $\begin{array}{l}\text { Agrarager } \\
\text { (g) }\end{array}$ & $\begin{array}{l}\text { Asam Sitrat } \\
\text { (g) }\end{array}$ \\
\hline 1 & PI & 450 & 550 & 1,5 & 1,5 \\
\hline 2 & P2 & 500 & 500 & 1,5 & 1,5 \\
\hline 3. & P3 & 550 & 450 & 1,5 & 1,5 \\
\hline 4 & P4 & 600 & 400 & 1,5 & 1,5 \\
\hline 5 & P5 & $6: 0$ & 350 & 1,5 & 1,5 \\
\hline
\end{tabular}

\section{Prosedur Penelitian}

Prosedur penelitian diawali dengan penyiapan bahan baku kemudian dilanjutkan dengan pembuataan seleai. Buah naga yang diperoleh dari Desa Maku, Kecamatan Dolo Kabupaten Sigi dengan ciri buah sudah berwarna merah menyeluruh pada permukaan kulit dan jumbai buah. Buah dibersihkan dari semut maupun kotoran yang melekat. Sebagian dari buah naga tersebut dianalisis untuk mengetahui kadar vitamin $\mathrm{C}$ dan antosianin, sisanya dibuat menjadi selai. Pembuatan selai, buah buah naga di potong-potong kecil menggunakan talenan dan ditimbang sesuai perlakuan. Kemudian dihaluskan dengan blender (tanpa menggunakan air) dengan kecepatan rendah (tombol 1) selama 3 menit. Setelah diblender bubur buah naga tersebut dimasukkan ke dalam panci lalu ditambahkan gula pasir sesuai perlakuan, agaragar $1,5 \mathrm{~g}$ dan asam sitrat $1,5 \mathrm{~g}$. Campuran di masak dengan suhu $80{ }^{\circ} \mathrm{C}$ selama 35 menit sambil diaduk agar homogen sampai mengental dan terbentuk selai buah naga. Proses pemasakan dihentikan apabila adonan meleleh tidak lama setelah sendok diangkat (spoon test), maka pemasakan telah cukup kemudian didinginkan. Selai dimasukan dalam wadah kaca dan ditutup rapat. kemudian dianalisis karakteristik fisik (kelunakan), kimia (kadar air, total padatan terlarut, kadar antosianin dan vitamin C) serta uji organoleptik (warna, rasa, tekstur dan kesukaan).

\section{Pengamatan}

Kelunakan

Analisis kelunakan selai menggunakan penetrometer. Power rheotex dinyalakan, jarum rheotex diletakkan tepat diatas tempat uji. Jarak diatur dengan kedalaman $2 \mathrm{~mm}$, dengan menekan tombol distance dan tombol hold secara bersamaan. Selai diletakkan pada tempat uji tepat dibawah jarum rheotex, selanjutnya ditekan tombol start selama beberapa detik sampai terdengar tanda bunyi selesai, kemudian dilanjutkan dengan membaca angka yang ditunjukkan jarum rheotex yaitu dengan satuan $\mathrm{mm}$ kedalam tusukan/beban 100g. Pengukuran ini dilakukan sebanyak lima kali dan hasil akhir diperoleh dari nilai rata-rata angka rheotex.

Kadar air (AOAC, 1990)

Cawan kosong dibersihkan, lalu diberi label kemudian dipanaskan di dalam oven pada suhu $105^{\circ} \mathrm{C}$ selama 15 menit, kemudian ditimbang. Sampel ditimbang di dalam cawan sebanyak \pm 5 g. Cawan beserta isinya dipanaskan di dalam oven pada suhu $105^{\circ} \mathrm{C}$ selama 2 jam. Dipindahkan ke dalam desikator, lalu didinginkan kemudian ditimbang. Dipanaskan kembali di dalam oven hingga diperoleh berat yang tetap. Nilai kadar air bahan diperoleh melalui persamaan :

(BS + BCK) - (BC+I)

Kadar Air (\%) =---- 100

BS

Keterangan

$\begin{array}{lll}\text { BCK } & : \text { Berat cawan kosong } \\ (\mathrm{BC}+\mathrm{I})^{*} & : \begin{array}{l}\text { Berat cawan dengan sampel } \\ \text { setelah dipanaskan }\end{array} \\ \mathrm{BS} & : \text { Berat sampel }\end{array}$

Total padatan terlarut (Chiralt, et al., 2001).

Penentuan total padatan terlarut (\% Brix) selai dilakukan dengan cara menggunakan refraktometer. Prosedur pengukurannya sampel diaduk sampai homogen, kemudian disaring melalui kain saring. Filtrat hasil penyaringan ditampung. Kemudian filtrat diteteskan pada prisma refraktometer. Dibaca skala pada alat dan dicatat suhu pengukuran.

Kadar antosianin (Less dan Francis, 1982dalam Ariani, 2012).

Sampel ditimbang untuk mengetahui bobot segarnya. Sampel digerus dalam lumpang lalu dilarutkan dalam etanol : HC1 $1 \mathrm{~N}(85: 15 \mathrm{~V} / \mathrm{V})$ sampai campuran menjadi homogen. Supernatan disaring kedalam labu takar $25 \mathrm{ml}$. Pengukuran 
absorban menggunakan spektrofotometer pada panjang gelombang $535 \mathrm{~nm}$.

Perhitungan :

\begin{tabular}{|c|c|}
\hline & D535 X Fp X W X 100\% \\
\hline $\begin{array}{l}\text { Antosia } \\
\text { (mg/10 }\end{array}$ & $\begin{array}{l}\text { in total = } \\
\text { g) }\end{array}$ \\
\hline Keter: & $\operatorname{gan}$ \\
\hline D535 & $\begin{array}{l}\text { nilai absorban pada panjang } \\
\text { gelombang } 535 \mathrm{~nm}\end{array}$ \\
\hline $\mathrm{Fp}$ & : faktor pengenceran \\
\hline W & $\begin{array}{l}\text { bobot segar sampel yang diukur } \\
\text { kandungan antosianinnya }\end{array}$ \\
\hline 98,2 & $\begin{array}{l}\text { nilai } E^{1 \%} \text { untuk pelarut Ethanol- } \\
\mathrm{HCl}\end{array}$ \\
\hline
\end{tabular}

Perhitungan :

X-Y
$\begin{aligned} & \text { Perubahan kadar }= \\ & \text { antosianin }(\%)\end{aligned}$------- x 100

Keterangan

$\mathrm{X}$ : Kadar antosianin buah naga segar $(\mathrm{mg} / 100 \mathrm{~g})$

Y : Kadar antosianin selai buah naga $(\mathrm{mg} / 100 \mathrm{~g})$

\section{Kadar vitamin C (AOAC, 1990)}

Sebanyak $5 \mathrm{~g}$ sampel ditimbang kemudian dihancurkan dengan menggunakan lumpang hingga membentuk slurry, lalu dimasukkan ke dalam labu takar $100 \mathrm{ml}$ dan ditambahkan aquades sampai tanda tera. Selanjutnya disentrifuge untuk memperoleh filtratnya. Filtratnya diambil sebanyak $25 \mathrm{ml}$ dengan menggunakan pipet dan dimasukkan ke dalam erlenmeyer lalu ditambahkan $2 \mathrm{ml}$ amilum $1 \%$ kemudian dititrasi dengan iodium $0,01 \mathrm{~N}$.

Perhitungan :

$$
\text { Vitamin C (mg/g) = } \frac{\text { V x N x 0,88 x Fp }}{\text { Berat Sampel }(g)}
$$

Keterangan

$\mathrm{V} \quad$ : Volume titrasi iodium $(\mathrm{ml})$

$\mathrm{N} \quad$ : Normalitas iodium $(0,01)$

0,88 : Kesetaraan antara ml iodium dengan mg asam askorbat

Fp : Faktor pengencer

Perhitungan :

Perubahan kadar $=$------------

vitamin $\mathrm{C}(\%) \quad \mathrm{X}$
Keterangan

$\mathrm{X}$ : Kadar vitamin $\mathrm{C}$ buah naga segar (mg/100 g)

$\mathrm{Y}$ : Kadar vitamin $\mathrm{C}$ selai buah naga $(\mathrm{mg} / 100 \mathrm{~g})$

\section{Uji organoleptik}

Menurut Waysima, dkk., (2010), uji organoleptik atau evaluasi sensoris merupakan suatu pengukuran ilmiah dalam mengukur dan menganalisa karakteristik suatu bahan pangan yang diterima oleh indera penglihatan, pencicipan, penciuman, perabaan, dan menginterpretasikan reaksi dari akibat proses penginderaan yang dilakukan oleh manusia yang juga bisa disebut panelis sebagai alat ukur. Dalam penelitian ini, peneliti menggunakan uji kesukaan terhadap warna, aroma, rasa dan kesukaan yang merupakan bagian dari uji organoleptik. Menurut Sofiah dan Achsyar (2008), uji kesukaan atau uji hedonik merupakan uji dimana panelis diminta memberi tanggapan secara pribadi tentang kesukaan atau ketidaksukaan beserta tingkatannya. Untuk keperluan ini digunakan panelis agak terlatih terdiri dari 20 orang yang sebelumnya dilatih untuk mengetahui sifat-sifat tertentu (pengujian organoleptic, 2013). Skala penilaian uji ini ditunjukkan pada Tabel 2.

Tabel 2. Skala Penilaian Uji Organoleptik

\begin{tabular}{lc}
\hline Skala Hedonik & Skala Numerik \\
\hline Sangat suka & 5 \\
Suka & 4 \\
Netral (sedang) & 3 \\
Tidak suka & 2 \\
Sangat tidak suka & 1 \\
\hline
\end{tabular}

\section{Hasil dan Pembahasan}

\section{Kelunakan}

Kelunakan dalam penelitian ini adalah besarnya beban yang diberikan oleh alat penetrometer dengan satuan $\mathrm{mm}$ kedalam tusukan/beban 100g. Semakin besar nilai yang tertera pada layar penetrometer semakin lunak sampel yang dianalisis. Rasio buah naga-gula pasir pengaruhnya sangat nyata terhadap kelunakan selai. Berdasarkan data pada Gambar 1 menunjukkan bahwa nilai rata-rata kelunakan selai terendah (paling keras) ditemukan pada perlakuan P1, pengaruhnya tidak berbeda nyata dengan P2 dan P3.Sebaliknya kelunakan tertinggi 
(paling lunak) diperoleh pada perlakuan P5 pengaruhnya tidak berbeda nyata dengan $\mathrm{P} 4$, tetapi sangat nyata berbeda dengan P1, P2 dan P3.

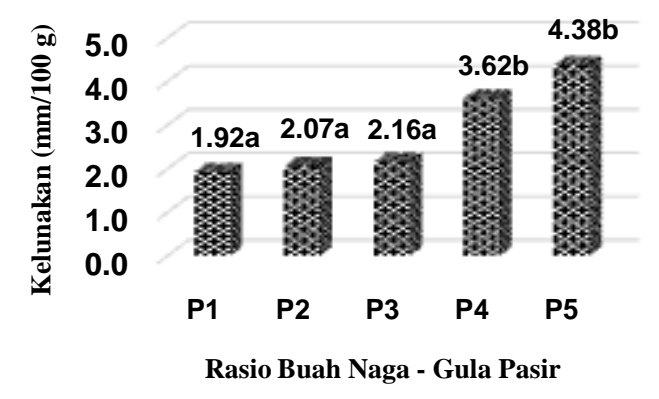

Keterangan :

$\mathrm{P} 1=$ buah naga $450 \mathrm{~g}$ : gula pasir $550 \mathrm{~g}, \mathrm{P} 2=$ buah naga $500 \mathrm{~g}$ : gula pasir $500 \mathrm{~g}, \mathrm{P} 3=$ buah naga $550 \mathrm{~g}$ : gula pasir $450 \mathrm{~g}, \mathrm{P} 4=$ buah naga $600 \mathrm{~g}$ : gula pasir $400 \mathrm{~g}, \mathrm{P} 5=$ buah naga $650 \mathrm{~g}$ : gula pasir $350 \mathrm{~g}$. BNJ $0,01=0,87$.

Gambar 1. Kelunakan selai buah naga pada berbagai ratio buah naga-gula pasir.

Data pada Gambar 1 terdapat hubungan linear $\left(\mathrm{y}=0.6467 \mathrm{x}+0.8889, \mathrm{r}=0.93^{* *}\right)$ antara rasio buah naga-gula pasir dengan kelunakan selai. Hal ini menunjukkan bahwa peningkatan berat daging buah naga dan penurunan berat gula pasir akan diikuti dengan peningkatan kelunakan selai sebesar 93 persen. Hasil tersebut menunjukkan bahwa semakin tinggi perbandingan buah naga terhadap gula pasir maka semakin tinggi pula nilai kelunakannya. Hasil penelitian ini serupa yang dilaporkan oleh Wahyuni (2012) bahwa semakin banyak daging buah naga merah yang ditambahkan maka semakin besar nilai kelunakan jenang yang dihasilkan atau semakin empuk. Sebaliknya semakin sedikit daging buah naga merah yang ditambahkan semakin kecil nilai kelunakan atau semakin keras. Meningkatnya nilai kelunakan dengan meningkatnya proporsi penambahan daging buah naga merah akan menyebabkan kandungan air selai meningkat sehingga kelunakan semakin lunak, sebaliknya semakin sedikit daging buah ditambahkan kelunakannya makin berkurang (semakin keras) karena kadar ainya kurang. Winarno (2008) mengatakan bahwa kadar air dapat mempengaruhi penampakan dan kelunakan suatu bahan pangan. Sehingga selai yang memiliki kadar air yang lebih rendah cenderung memiliki kelunakan yang lebih keras dibandingkan selai yang memiliki kadar air lebih tinggi. Oleh karena itu rendahnya kelunakan selai hasil perlakuan P1 karena kadar airnya lebih rendah daripada perlakuan lainnya (Gambar 2). Sebaliknya kadar air selai yang tinggi pada perlakuan P5 menyebabkan kelunakannya meningkat.

\section{Kadar air}

Rasio buah naga-gula pasir pengaruhnya sangat nyata terhadap kadar air selai. Berdasarkan data pada Gambar 2 menunjukkan bahwa nilai rata-rata kadar air selai terendah ditemukan pada perlakuan P1, pengaruhnya tidak berbeda nyata dengan P2, P3 dan P4. Sebaliknya kadar air tertinggi diperoleh pada perlakuan P5 pengaruhnya tidak berbeda nyata dengan $\mathrm{P} 4, \mathrm{P} 3$ dan P2, tetapi sangat nyata berbeda dengan P1.

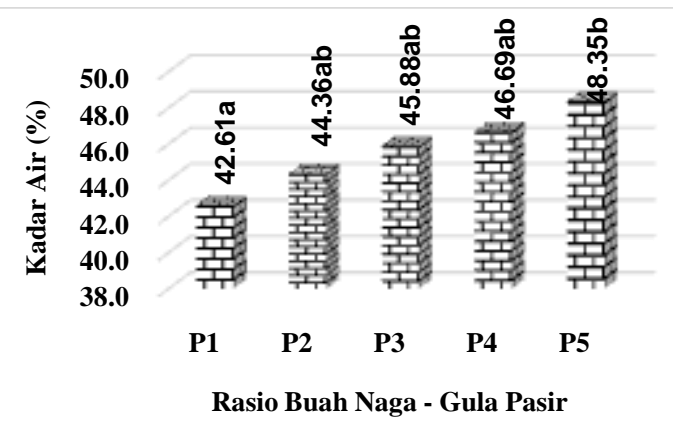

Keterangan :

$\mathrm{P} 1$ = buah naga $450 \mathrm{~g}$ : gula pasir $550 \mathrm{~g}, \mathrm{P} 2=$ buah naga $500 \mathrm{~g}$ : gula pasir $500 \mathrm{~g}, \mathrm{P} 3=$ buah naga $550 \mathrm{~g}$ : gula pasir $450 \mathrm{~g}, \mathrm{P} 4=$ buah naga $600 \mathrm{~g}$ : gula pasir $400 \mathrm{~g}, \mathrm{P} 5$ = buah naga $650 \mathrm{~g}$ : gula pasir $350 \mathrm{~g}$. BNJ $0,01=5,00$.

Gambar 2. Kadar air selai buah naga pada berbagai ratio buah naga-gula pasir.

Data pada Gambar 2 terdapat hubungan linear $(\mathrm{y}=1.382 \mathrm{x}+41.431, \mathrm{r}=0.99 * *)$ antara rasio buah naga-gula pasir dengan kadar air selai. Hal ini menunjukkan bahwa peningkatan berat daging buah naga dan penurunan berat gula pasir akan diikuti dengan peningkatan kadar air sebesar 99 persen. Beberapa hasil penelitian sebelumnya melaporkan bahwa buah naga mengandung air sebesar 86,03\% (Jerônimo, et al., 2015), 82,5 83\% (Jaafar, et al., 2009) dan 87,90\% (Islam, et al., 2012). Oleh karena itu meningkatnya proporsi penambahan daging buah naga merah akan menyebabkan kandungan air selai meningkat. Sebaliknya semakin sedikit proposi daging buah dan semakin besar proporsi gula pasir kadar air selai akan berkurang. Penambahan gula mengakibatkan penurunan kadar air selai, hal ini disebabkan semakin 
banyak gula yang ditambahkan mengakibatkan waktu pemasakan selai lebih lama, sehingga memungkinkan lebih banyak air yang teruapkan dan menyebabkan kadar air selai semakin rendah.

\section{Total padatan terlarut}

Total padatan terlarut menunjukkan kandungan bahan-bahan yang terlarut dalam larutan. Komponen yang terkandung dalam buah terdiri atas komponen-komponen yang larut air seperti glukosa, pectin, fruktosa, sukrosa, dan protein yang larut air. Rasio buah naga-gula pasir pengaruhnya sangat nyata terhadap total padatan terlarut selai. Data pada Gambar 3 menunjukkan bahwa nilai rata-rata total padatan terlarut selai terendah ditemukan pada perlakuan P5, pengaruhnya tidak berbeda nyata dengan $\mathrm{P} 4$, tetapi sangat nyata berbeda dengan P3, P2 dan P1. Sebaliknya total padatan terlarut tertinggi diperoleh pada perlakuan P1 pengaruhnya berbeda sangat nyata dengan P2, P3, P4 dan P5.

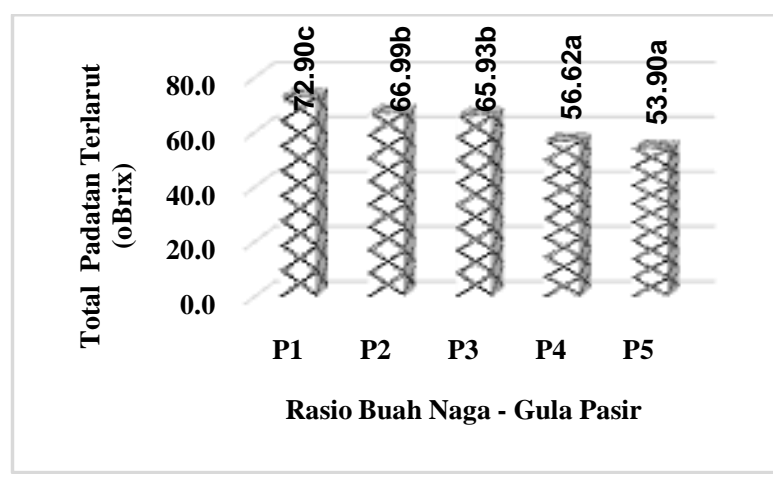

Keterangan :

$\mathrm{P} 1$ = buah naga $450 \mathrm{~g}$ : gula pasir $550 \mathrm{~g}, \mathrm{P} 2=$ buah naga $500 \mathrm{~g}$ : gula pasir $500 \mathrm{~g}, \mathrm{P} 3=$ buah naga $550 \mathrm{~g}$ : gula pasir $450 \mathrm{~g}, \mathrm{P} 4=$ buah naga $600 \mathrm{~g}$ : gula pasir $400 \mathrm{~g}, \mathrm{P} 5 \mathrm{=}$ buah naga $650 \mathrm{~g}$ : gula pasir $350 \mathrm{~g}$. BNJ $0,01=5,34$

Gambar 3. Total padatan terlarut selai buah naga pada berbagai ratio buah naga-gula pasir.

Data pada Gambar 3 terdapat hubungan linear negative $\left(\mathrm{y}=-4,8364 \mathrm{x}+77,778 \mathrm{r}=0.98^{* *}\right)$ antara rasio buah naga-gula pasir dengan total padatan terlarut. Hal ini menunjukkan bahwa peningkatan berat daging buah naga dan penurunan berat gula pasir akan diikuti dengan penurunan total padatan terlarut sebesar 98 persen. Sebaliknya penurunan berat buah naga dan peningkatan berat gula pasir akan menyebabkan peningkatan total padatan terlarut. Buah naga mengandung total padatan terlarut 11,0 - $11,40{ }^{\circ}$ Brix pada suhu $20^{\circ} \mathrm{C}$ (Jerônimo, et al., 2015 dan Islam, et al., 2012). Sukrosa dan pektin berperan untuk meningkatkan kadar total padatan terlarut. Winarno (2008) menyatakan bahwa total padatan terlarut dipengaruhi oleh pektin yang larut, sedangkan penambahan gula pasir (sukrosa) juga merupakan salah satu faktor yang mempengaruhi total padatan terlarut. Ketika buah naga tersebut diolah menjadi selai dan ditambahkan bahan padat (gula pasir), maka total padatan terlarutnya akan meningkat. Menurut Buckle, et al., (2007), semakin tinggi konsentrasi sukrosa yang terkandung dalam suatu buah yang sudah matang akan menghasilkan total padatan terlarut yang tinggi.

\section{Kadar antosianin}

Buah naga merah memiliki warna merah yang sangat menarik yang disebut antosianin. Antosiain merupakan pewarna yang paling penting dan paling banyak tersebar luas dalam tumbuhan. Rasio buah naga-gula pasir pengaruhnya sangat nyata terhadap kadar antosianin selai selai. Data pada Gambar 4 menunjukkan bahwa nilai rata-rata kadar antosianin selai terendah ditemukan pada perlakuan $\mathrm{P} 1$, pengaruhnya tidak berbeda nyata dengan P2, tetapi sangat nyata berbeda dengan P3, P4 dan P5. Sebaliknya kadar antosianin tertinggi diperoleh pada perlakuan P5 pengaruhnya tidak berbeda dengan $\mathrm{P} 4$ tetapi sangat nyata berbeda dengan P3, P2 dan P1.

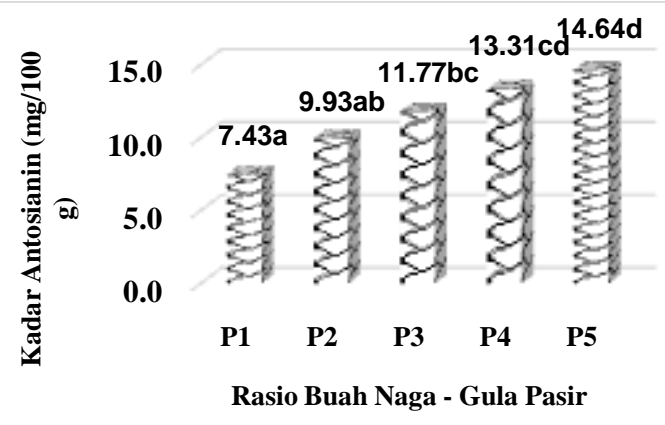

Keterangan :

$\mathrm{P} 1$ = buah naga $450 \mathrm{~g}$ : gula pasir $550 \mathrm{~g}, \mathrm{P} 2=$ buah naga $500 \mathrm{~g}$ : gula pasir $500 \mathrm{~g}, \mathrm{P} 3=$ buah naga $550 \mathrm{~g}$ : gula pasir $450 \mathrm{~g}, \mathrm{P} 4=$ buah naga $600 \mathrm{~g}$ : gula pasir $400 \mathrm{~g}, \mathrm{P} 5$ = buah naga $650 \mathrm{~g}$ : gula pasir $350 \mathrm{~g}$. BNJ $0,01=2,72$

Gambar 4. Kadar antosianin selai buah naga pada berbagai ratio buah naga-gula pasir.

Data yang tersaji pada Gambar 4 menunjukkan adanya hubungan linear ( $\mathrm{y}=$ $1.7797 \mathrm{x}+6.0771, \mathrm{r}=0,99 * *)$ antara rasio buah naga-gula pasir dengan kadar antosianin selai. Hubungan ini menunjukkan bahwa peningkatan 
berat daging buah naga dan penurunan berat gula pasir akan diikuti dengan peningkatan kadar antosianin selai sebesar 99 persen. Kadar antosianin buah naga berkisar antara 28,7 - 55,6 $\mathrm{mg} / 100 \mathrm{~g}$ atau rata-rata $42,15 \mathrm{~g} / 100 \mathrm{~g}$ buah segar (Vargas, et al., 2013). Jika berat buah naga ditingkatkan dan gula pasir diturunkan, maka kadar antosianin selai yang dihasilkan akan meningkat.

Kadar antosiani selai bila buah naga berkisar 7,43 - 14,64 mg/100 g (Gambar 4). Jika dibandingkan dengan rata-rata kadar antosianin buah naga tersebut di atas, berarti kadar antosianinnya berkurang setelah diolah menjadi selai antara 27,51 - 34,72 mg/100 g.Persentase penurunan kadar antosianin berturut-turut tertinggi pada $\mathrm{P} 1=81,95 \%, \mathrm{P} 2=75,87 \%, \mathrm{P} 3=$ $71,39 \%, \mathrm{P} 4=67,65 \%$ dan $\mathrm{P} 5=64,43 \%$. Berdasarkan hasil ini dapat dinyatakan bahwa semakin tinggi berat daging buah naga dan semakin rendah berat gula pasir akan diikuti dengan berkurangnya penurunan kadar antosianin selai. Sebaliknya penurunan kadar antosianin meningkat jika berat daging buah naga rendah dan berat gula pasir tinggi. Penurunan kadar antosianin tersebut disebabkan adanya pengaruh panas. Pemanasan selama lebih dari 30 menit akan mengurangi kadar antosianin lebih dari $50 \%$. Semakin tinggi suhu pemanasan, semakin banyak pula antosianin yang rusak. Demikian juga dengan lama waktu pemanasan, semakin lama waktu pemanasan, semakin banyak pula jumlah antosianin yang terdegradasi. Proses pemanasan terbaik untuk mencegah kerusakan antosianin adalah pengolahan pada suhu tinggi, tetapi dalam jangka waktu yang sangat pendek (High Temperature Short Time (HTST)) (Garcia dkk, 2001).

\section{Kadar vitamin C}

Rasio buah naga-gula pasir pengaruhnya sangat nyata terhadap kadar vitamin $\mathrm{C}$ selai. Data pada Gambar 5 menunjukkan bahwa nilai rata-rata kadar vitamin $\mathrm{C}$ selai terendah ditemukan pada perlakuan $\mathrm{P} 1$, pengaruhnya tidak berbeda nyata dengan $\mathrm{P} 2$, tetapi sangat nyata berbeda dengan P3, P4 dan P5. Sebaliknya kadar vitamin $\mathrm{C}$ tertinggi diperoleh pada perlakuan P5 pengaruhnya berbeda sangat nyata perlakuan $\mathrm{P} 4$, P3, P2 dan P1.

Menurut Islam, et al., (2012) kandungan vitamin $C$ buah naga segar 9,90 mg/100 g. Sedangkan kandungan vitamin $\mathrm{C}$ selai buah naga hasil penelitian ini berkisar antara 1,04 - 3,38 $\mathrm{mg} / 100 \mathrm{~g}$ (Gambar 5). Hasil ini ini menunjukkan bahwa bila buah naga diolah menjadi selai kandungan vitamin $\mathrm{C}$ akan berkurang antara 6.42 - 8,86 mg/100 g. Pesentase penurunan kadar vitamin $\mathrm{C}$ secara berturut-turut tertinggi pada perlakuan $\mathrm{P} 1=89,48 \%, \mathrm{P} 2=86,94, \mathrm{P} 3=$ $77,70 \%, \mathrm{P} 4=72.61 \%$ dan $\mathrm{P} 5=64,54 \%$.

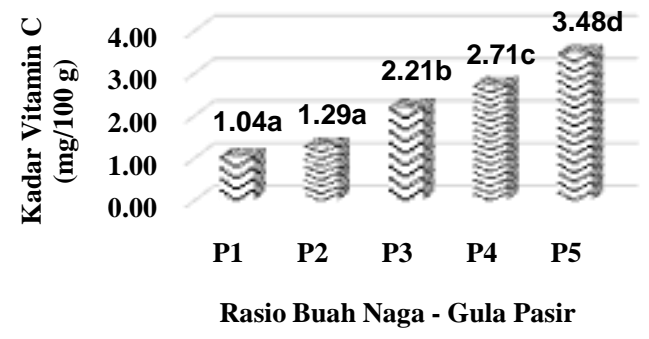

Keterangan :

$\mathrm{P} 1$ = buah naga $450 \mathrm{~g}$ : gula pasir $550 \mathrm{~g}, \mathrm{P} 2=$ buah naga $500 \mathrm{~g}$ : gula pasir $500 \mathrm{~g}, \mathrm{P} 3=$ buah naga $550 \mathrm{~g}$ : gula pasir $450 \mathrm{~g}, \mathrm{P} 4=$ buah naga $600 \mathrm{~g}$ : gula pasir $400 \mathrm{~g}, \mathrm{P} 5=$ buah naga $650 \mathrm{~g}$ : gula pasir $350 \mathrm{~g}$. BNJ $0,01=0,33$

Gambar 5. Kadar vitamin C selai buah naga pada berbagai ratio buah naga-gula pasir.

Berdasarkan hasil ini dapat dinyatakan bahwa semakin tinggi berat daging buah naga dan semakin rendah berat gula pasir akan diikuti dengan berkurangnya penurunan kadar vitamin $\mathrm{C}$ selai. Sebaliknya penurunan kadar vitamin $C$ meningkat jika berat daging buah naga rendah dan berat gula pasir tinggi. Penurunan kadar vitamin $\mathrm{C}$ pada buah naga merah ini disebabkan adanya pemanasan selama pengolahan (proses pemasakan). Suhu pemasakan dapat menyebabkan terjadinya degradasi vitamin $\mathrm{C}$ sehingga mampu mempercepat terjadinya oksidasi vitamin C.

\section{Uji Organoleptik}

Uji organoleptik selai yang diamati dalam penelitian ini meliputi warna, tekstur, rasa dan kesukaan. Perlakuan rasio daging buah naga gula pasir berpengaruhsangat nyata terhadap warna, tekstur, rasa dan kesukaan selai. Nilai rata-rata warna, tekstur, rasa dan kesukaan selai disajikan pada Tabel 3.

\begin{tabular}{lcccc} 
Tabel & \multicolumn{3}{c}{ Nilai Skor Uji Organoleptik Selai pada } \\
3. & \multicolumn{4}{c}{ Berbagai Rasio Buah Naga-Gula Pasir } \\
\hline \multirow{2}{*}{$\begin{array}{l}\text { Perlaku } \\
\text { an }\end{array}$} & \multicolumn{3}{c}{ Rata-rata Nilai Skor Uji Organoleptik } \\
\cline { 2 - 5 } Warna & Tekstur & Rasa & Kesukaan \\
\hline P1 & $2.10^{\mathrm{a}}$ & $1.75^{\mathrm{a}}$ & $2.25^{\mathrm{a}}$ & $2.55^{\mathrm{a}}$ \\
P2 & $2.55^{\mathrm{ab}}$ & $2.00^{\mathrm{ab}}$ & $2.50^{\mathrm{a}}$ & $2.60^{\mathrm{a}}$ \\
P3 & $3.10^{\mathrm{b}}$ & $2.45^{\mathrm{b}}$ & $3.30^{\mathrm{b}}$ & $3.40^{\mathrm{bc}}$ \\
P4 & $4.05^{\mathrm{c}}$ & $2.60^{\mathrm{b}}$ & $3.75^{\mathrm{b}}$ & $4.00^{\mathrm{c}}$
\end{tabular}




\begin{tabular}{lcccc} 
P5 & $3.75^{\mathrm{c}}$ & $2.25^{\mathrm{ab}}$ & $3.60^{\mathrm{b}}$ & $3.65^{\mathrm{c}}$ \\
\hline $\mathrm{BNJ}$ & & & & \\
0,01 & 0,61 & 0,60 & 0,72 & 0,76 \\
\hline
\end{tabular}

Keterangan :

$\mathrm{P} 1$ = buah naga $450 \mathrm{~g}$ : gula pasir $550 \mathrm{~g}, \mathrm{P} 2=$ buah naga $500 \mathrm{~g}$ : gula pasir $500 \mathrm{~g}, \mathrm{P} 3=$ buah naga $550 \mathrm{~g}$ : gula pasir $450 \mathrm{~g}, \mathrm{P} 4=$ buah naga $600 \mathrm{~g}$ : gula pasir $400 \mathrm{~g}, \mathrm{P} 5$ = buah naga $650 \mathrm{~g}$ : gula pasir $350 \mathrm{~g}$. Nilai rata-rata yang dikuti oleh huruf yang sama pada kolom yang sama tidak berbeda nyata pada taraf uji BNJ 0,01 .

\section{Warna}

Data pada Tabel 3 perlakuan P4 memberikan selai buah naga yang memiliki skor warna tertinggi yakni 4,05 (suka - sangat suka), pengaruhnya tidak berbeda nyata $\mathrm{P} 5$ tetapi sangat nyata berbeda dengan perlakuan P3, P2 dan P1. Sebaliknya nilai skor warna selai terendah 2,1 (tidak suka - netral) ditemukan pada perlakuan $\mathrm{P} 1$, pengaruhnya tidak berbeda nyata $\mathrm{P} 2$ tetapi sangat nyata berbeda dengan perlakuan P3, P4 dan P5. Hasil analisa korelasi menunjukkan bahwa terdapat hubungan kuadratik $(\mathrm{y}=$ $\left.0.0714 \mathrm{x}^{2}+0.7886 \mathrm{x}+1.66, \mathrm{r}=0.91^{* *}\right)$ antara ratio buah naga - gula pasir dengan nilai skor warna. Hubungan ini memberi arti bahwa nilai skor warna selai meningkat jika berat buah naga ditingkatkan dan berat gula diturunkan. Meskipun demikian pada ratio buah naga di atas $600 \mathrm{~g}$ : gula pasir $400 \mathrm{~g}$ (P4) nilai skor warnanya menurun. Buah naga mengandung antosianin 28,7 - 55,6 mg/100 g (Vargas, et al., 2013) yang berwarna merah. Oleh karena itu semakin tinggi penambahan berat buah naga akan menghasilkan selai dengan warna yang lebih disukai oleh panelis. Meskipun demikian jika penambahan berat buah naga terlalu banyak akan memberikan selai dengan warna merah gelap yang kurang disengi oleh panelis.

\section{Tekstur}

Data pada Tabel 3 perlakuan P4 memberikan selai buah naga dengan nilai skor tekstur tertinggi yakni 2.60 (tidak suka - netral), pengaruhnya tidak berbeda nyata dengan P2, P3 dan P5 tetapi sangat nyata berbeda dengan perlakuan P1. Sebaliknya nilai skor tekstur selai terendah 1,75 (sangat tidak suka - tidak suka) ditemukan pada perlakuan P1, pengaruhnya tidak berbeda nyata P2 dan P5 tetapi sangat nyata berbeda dengan perlakuan P3 dan P4.

Hasil analisa korelasi menunjukkan bahwa terdapat hubungan kuadratik $\left(\mathrm{y}=-0.1071 \mathrm{x}^{2}+\right.$ $0.8029 x+0.98, r=0.94 * *)$ antara ratio buah naga - gula pasir dengan tekstur. Hubungan ini memberi arti bahwa nilai skor tekstur selai meningkat (disenagi oleh panelis) jika berat buah naga dinaikkan dan berat gula diturunkan. Meskipun demikian pada ratio buah naga di atas $600 \mathrm{~g}$ : gula pasir $400 \mathrm{~g}$ (P4) nilai skor teksturnya menurun (kurang disenangi oleh panelis). Kekerasan gel pada selai tergantung kepada konsentrasi gula, pektin, dan asam (Hasbullah, 2001). Semakin banyak gula pasir yang ditambahkan maka kelunakan selai yang dihasilkan akan semakin keras, begitu juga sebaliknya semakin banyak bubur buah naga merah yang digunakan maka kelunakan selai yang dihasilkan semakin lembut. Menurut Ropiani (2006) kelunakan adalah salah satu sifat penting produk selai, apabila kelunakan terlalu keras akan membuat selai sulit untuk dioles dan biasanya dapat menurunkan penerimaan panelis terhadap produk selai yang dihasilkan. Selai yang baik adalah selai yang memiliki kelunakan tidak terlalu keras dan tidak terlalu encer. Hal ini disebabkan selai yang terlalu kental atau keras akan sulit dioleskan dan selai yang terlalu encer akan membuat selai juga sulit untuk dioleskan.

Rasa

Data pada Tabel 3 perlakuan P4 memberikan selai buah naga dengan nilai skor rasa tertinggi yakni 3,75 (netral - suka), pengaruhnya tidak berbeda nyata dengan P3 dan P4 tetapi sangat nyata berbeda dengan perlakuan P1 dan P2. Sebaliknya nilai skor rasa selai terendah 2,25 (tidak suka - netral) ditemukan pada perlakuan $\mathrm{P} 1$, pengaruhnya tidak berbeda nyata $\mathrm{P} 2$ tetapi sangat nyata berbeda P3, P4 dan P5.

Hasil analisa korelasi menunjukkan bahwa terdapat hubungan kuadratik $\left(\mathrm{y}=-0.0821 \mathrm{x}^{2}+\right.$ $\left.0.8879 \mathrm{x}+1.32, \mathrm{r}=0.96^{* *}\right)$ antara ratio buah naga - gula pasir dengan rasa. Hubungan ini memberi arti bahwa nilai skor rasa selai meningkat (lebih disenangi oleh panelis) jika berat buah naga dinaikkan dan berat gula diturunkan. Meskipun demikian pada ratio buah naga di atas $600 \mathrm{~g}$ : gula pasir $400 \mathrm{~g}$ (P4) nilai skor rasanya menurun (kurang disenangi oleh panelis).

Kesukaan

Data pada Tabel 3 perlakuan P4 memberikan selai buah naga dengan nilai skor kesukaan tertinggi yakni 4,00 (suka), pengaruhnya tidak berbeda nyata dengan $\mathrm{P} 3$ dan P4 tetapi sangat nyata berbeda dengan perlakuan P1 dan P2. Sebaliknya nilai skor rasa selai terendah 2,25 (tidak suka - netral) ditemukan 
pada perlakuan $\mathrm{P} 1$, pengaruhnya tidak berbeda nyata $\mathrm{P} 2$ tetapi sangat nyata berbeda $\mathrm{P} 3, \mathrm{P} 4$ dan P5. Kesukaan pada hakekatnya adalah kesimpulan yang diperoleh dari panelis terhadap warna, tekstur dan rasa. Menurut Soekarto, (2002) uji tingkat kesukaan merupakan uji penerimaan secara keseluruhan (overvall) panelis terhadap suatu produk setelah menilai warna, aroma dan rasanya. Hal ini terlihat pada Tabel 3 yang menunjukkan bahwa perlakuan P4 memberikan nilai skor tertinggi terhadap warna, tekstur dan rasa selai. Sehingga perlakuan P4 juga menghasilkan selai dengan nilai skor kesukaan tertinggi. Fenomena ini terlihat pada Gambar 6 yang menunjukkan bahwa semakin tinggi nilai skor rasa akan disertai dengan peningkatan nilai skor kesukaan.

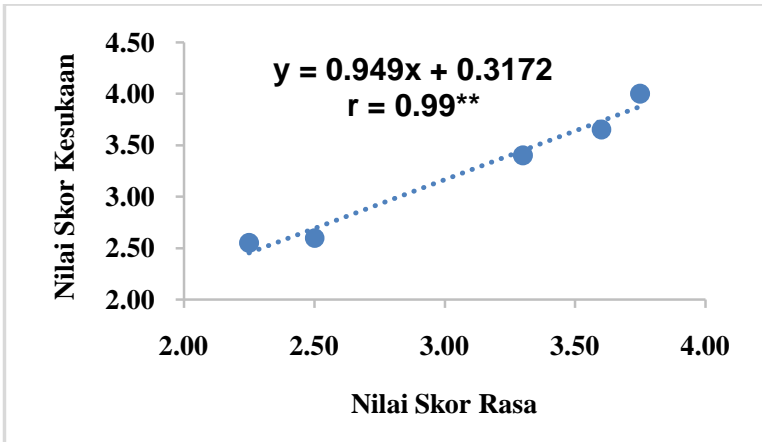

Gambar 6. Hubungan antara nilai skor rasa dengan kesukaan

\section{Kesimpulan}

Perlakuan P4 (rasio buah naga-gula pasir 600 : $400 \mathrm{~b} / \mathrm{b}$ ) memberikan pengaruh terbaik terhadap karakteristik fisik, kimia dan organoleptik selai buah naga. Perlakuan ini dapat mengurangi pemakaian gula pasir sebesar 15 persen dari standar penggunaan gula dalam pembuatan selai.

\section{Daftar Pustaka}

AOAC. 1990. Official Methods of Analysis. Washington: Association of Official Analytical Chemist.

Ariani, 2012. Pengaruh Kuantitas Cahaya Terhadap Pertumbuhan dan Kadar Antosianin Daun Dewa (Gynura Pseudochina (L.) Dc) Secara In Vitro. [Skripsi] Jurusan Budidaya Pertanian. Universitas Tadulako. Palu.

Buckle, K. A., R. A. Edwards, G. H. Fleet dan, M. Wootton, 2007. Ilmu Pangan. Terjemahan H. Purnomo dan Adiano. Universitas Indonesia Press, Jakarta
Chiralt, A. N. Martinez-Navarette, J. MartinezMonzo, P. Talens, G. Moraga, A. Ayala, and P. Fito. 2001. Changes in Machanical Properties Throughout Osmotic Processes Cryoprotectant effect. J. Food Engin. 49:129135.

Garcia, Viguera., C. dan Zafrilla, P. 2001. Changes in anthocyanins food processing: influence on color, chemistry and physiology of selected food colorants. P. 56-65. ACS Symposium Series 775 American Chemical Society.

Hasbullah. 2001. Teknologi Tepat Guna Agroindustri Kecil Sumatera Barat. Dewan Ilmu Pengetahuan, Teknologi dan Industri. Sumatera Barat.

Islam, M. Z., M. T. H. Khan., M. M. Hoque and M. M. Rahman, 2012. Studies on the Processing and Preservation of Dragon Fruit (Hylocereus undatus) Jelly. The Agriculturists $10(2): 29-35$

Jaafar, R. A., A.R. Bin A. Rahman., N. Z.C. Mahmod and R.Vasudevan, 2009. Proximate Analysis of Dragon Fruit (Hylecereus polyhizus). Am. J. Applied Sci., 6 (7): 13411346

Jerônimo, M. C., J. V. C. Orsine., K. K. Borgesand M. R. C. G. Novaes, 2015. Chemical and Physical-Chemical Properties, Antioxidant Activity and Fatty Acids Profile of Red Pitaya [Hylocereus Undatus (Haw.) Britton \& Rose] Grown In Brazil. J. Drug Metab Toxicol 2015, 6 (4) : 1 - 6

Kristanto, D., 2013. Buah Naga Pembudidayaan di Pot dan di Kebun. Penebar Swadaya. Jakarta

Lichtenzveig, J., Abbo, S., Nerd, A., Tel-Zur, N. dan Mizrahi, Y. 2000. Cytology and Mating Systems in the Climbing Cacti Hylocereus and Selenicereus. American Journal of Botany. 87 : 1058-1065.

Mahattanatawee, K., JA. Manthey, G. Luzio, S.T Talcott, K. Goodner and E.A. Baldwin. (2006). Total antioxidant activity and fiber content of select Florida-grown tropical fruits. Journal Agric. Food Chem., 54; 7355-7363.

Pengujian organoleptic, 2013. Modul Penanganan Mutu Fisis (Organoleptik). Program Studi Teknologi Pangan Universitas Muhammadiyah Semarang 
Rizky dan Addina, 2012. Penggulaan dan Selai. [online]. Tersedia: http://www.scribd.com/doc/100213391/Pengg ulaan-Dan-Selai Diakses tanggal 23 Juli 2016. Universitas Dipenogoro: Semarang.

Ropiani. 2006. Karakterisasi fisik dan $\mathrm{pH}$ selai buah pepaya bangkok. SkriPRi Fakultas Matematika dan Ilmu Pengetahuan Alam. Institut Pertanian Bogor. Bogor.

Soekarto. 2002. Penilaian Organoleptik Untuk Industri Pangan dan Hasil Pertanian. Institut Pertanian Bogor. Bogor.

Sofiah, B. D., Achyar, T. S., 2008. Buku Ajar Kuliah Penilaian Indra.(Cetakan ke-1). Jatinangor: Universitas Padjadjaran.
Vargas, M. de Lourdes Vargas y., J.A. T. Cortez., E. S. Duch., A.P. Lizama and C. H. H. Méndez, 2013. Extraction and Stability of Anthocyanins Present in the Skin of the Dragon Fruit (Hylocereus undatus). Food and Nutrition Sciences, 4 : 1221-1228

Wahyuni, R., 2012. Pemanfaatan Buah Naga Super Merah (hylocereus costaricensis) dalam Pembuatan Jenang Dengan Perlakuan Penambahan Daging Buah yang Berbeda. Jurnal Teknologi Pangan 4(1) Universitas Yudharta Pasuruan: Pasuruan.

Winarno, F. G. 2008. Kimia Pangan dan Gizi. PT Gramedia Pustaka Utama. Jakarta.

Waysima, Adawiyah, R. Dede, 2010. Evaluasi Sensori (Cetakan ke-5). Bogor: Fakultas Teknologi Pertanian Institut Pertanian Bogor. 